\title{
Recent advances in engineering crop plants for resistance to insect pests
}

\author{
Shilpa Kamatham', Sandhya Munagapati ${ }^{2}$, Kota Neela Manikanta ${ }^{3}$, Rohith Vulchi ${ }^{4}$, Kiranmai Chadipiralla ${ }^{1}$, \\ Sri Hari Indla ${ }^{1}$ and Uday Sankar Allam ${ }^{1 *}$ (D)
}

\begin{abstract}
Background: While the rapidly increasing global population has led to a dramatically increased demand for the agricultural production, there have been heavy economic losses owing to various pest attacks on different food crops. The advancement of various biotechnological techniques have come as a boon in addressing the global concern and leads to the development of novel varieties that have proven to be highly economical, pesticide resistant and environmentally safe.

Main body: The present review was aimed to update the recent developments that have taken place in the field of crop production. Major focus was laid predominantly on such genes that have demonstrated positive effects and proved to be of commercial success at the market primarily due to the development of pest-resistant transgenic food crops with expression of Bacillus thuringiensis toxins. This technology has been effective against a wide range of pests including coleopterans, lepidopterans, hemipterans, dipterans, strongylida (nematodes) and rhabditida. In similar lines various plant derived toxic proteins were also discussed along with different genes that code for insect resistant proteins such as $\delta$-endotoxins and secreted toxins. This article also helps in understanding the structural features of the genes that are endowed with insect resistance followed by their mechanism of action on pests. Further the role of secondary metabolites in controlling the pests was addressed. The Pros and Cons of existing tools of insect pest management were demonstrated.
\end{abstract}

Conclusions: Novel technologies are necessary in crop improvement to progress the pace of the breeding programs, to confer insect resistance in crop plants. Therefore, the future aim of crop biotechnology is to engineer a sustainable, multi-mechanistic resistance to insect pests considering the diversity of plant responses to insect attack.

Keywords: Genetic engineering, Insect resistance, Toxins, CRISPR/Cas9, RNAi, Phytophagous, Stacked traits

\section{Background}

Genetic engineering is a deliberate process of making changes to the characteristics of an organism by changing its genetic material. Genetic engineering in crop plants mainly offers two advantages i.e., (1) combining several individual, commercially useful genes to form gene cassettes and (2) reducing the time to introgression of these genes into a single genetic background. Since the "first

\footnotetext{
*Correspondence: vsuusareddy@gmail.com

1 Department of Biotechnology, SPSR Bhavan, Vikrama Simhapuri

University, SPS Nellore 524 320, Andhra Pradesh, India

Full list of author information is available at the end of the article
}

report of genetically modified plants appeared in 1984 (Horsch et al. 1984), there has been a very rapid progress directed at using this novel technology for the practical ends of crop improvement. Protection of crop plants from insect pests was quickly seized upon as a major goal of plant genetic engineering (National Council 2000). The potential size of this market attracted major attention of a number of commercial organizations and the potential economic importance of this sector of biotechnology is "finally becoming more widely recognized (Burke and Thomas 1997). The practical application of plant genetic engineering involves two equally important technologies; cellular and molecular biology. The list of crop species 
which are amenable to genetic engineering has grown steadily and now includes majority of the crop species and many minor previously orphan crops. Concurrently, the list of useful genes for introduction into transgenic crops has not grown at a similar pace, although several different genes which might be useful for crop protection have been proposed. In this review, concentration was laid primarily on those genes which demonstrated effects in transgenic plants and their commercial success at the market. By far the greatest research effort in developing pest-resistant transgenic crops has gone into expression of Bacillus thuringiensis $(B t)$ toxins in plants (Flores et al. 2005).

\section{Main text}

\section{Phytophagous insects}

Insects belonging to the class Insecta are the most diverse group of arthropods and two thirds of them are phytophagous i.e. feed on living plant parts. Majority of the insect pests feed on one or few related plant species (monophagous) and few insects feed on multiple hosts (polyphagous). Intensity of crop damage by an insect depends upon the type of mouthparts which in turn decides the method of feeding. The insect feeding modes are broadly grouped into two types i.e., sucking/ houstellate type, biting and chewing type and accordingly their mouthparts are evolved to suit their feeding style. Insects with sucking type of mouthparts causes substantial harm to the crop plants by damaging the vascular system of the plant (phloem and xylem), impairing transportation of water, minerals and food. In addition to that, they also cause additional damage to crop plants by transporting disease causing pathogens such as bacteria, fungi and viruses (Yadeta and Thomma 2013). Aphids, whiteflies, leafhoppers, thrips and honeybees are the examples for piercing and sucking type of mouth parts. On the contrary, insects with biting and chewing type of mouth parts cause mechanical damages to plant parts as they chew plant tissues such as root, stem, leaf, flowers and fruits affecting water and mineral acquisition photosynthesis and seed set. Grasshoppers, beetles, moths are the examples for insects with chewing type of mouth parts (Douglas 2018). More than 500,000 insect species belonging to majorly 8 out of 36 insect orders are known to be phytophagous (Bensoussan et al. 2016). Phytophagy is very common in the insect pests belonging to Lepidoptera (moths and flies), Coleoptera (leaf beetles and weevils), Hemiptera (Aphids, Planthoppers, sucking bugs), Diptera (gall flies, leaf miners, fruit flies), Hymenoptera (sawflies, wasps), Thysanoptera (thrips), Orthoptera (locusts, grasshoppers, crickets) and Phasmatodea (leaf, stick insects) orders (Chapman 2009).

\section{Yield losses due to insect pest}

Annually, global yield losses due to insect pests were estimated to be $18-20 \%$ of the annual crop production estimated at a value of more than US $\$ 470$ billion (Sharma et al. 2017) and 30-35\% in Indian agriculture which costs around US $\$ 36$ billion, demonstrating adverse influence on the agricultural market, food security, and farmers profits. During the twenty-first century, these losses declined to 17.5 from $23.3 \%$ from the early 2000 s, a positive indicator which can be largely attributed to the increase in the use of transgenic crops (Dhaliwal et al. 2010). Apart from causing significant yield losses by direct damage, insect pests can also cause indirect damage by transmitting disease causing pathogens. Sustainable increase of global food production without causing ecological damage has gained importance and many developed countries started investing in the development of eco-friendly pest management tactics during the 1980s itself (Swanton and Weise 1991), particularly important to meet the increased food supply of the burgeoning human population by 2050 . This can be achieved by increasing the automation of agriculture concurrently utilizing biotechnological innovations. By 2050, growing-season temperatures will probably go beyond those documented in the past century and may significantly eases crop yield. On the other hand, models assessing the effects of climate warming on crop yields seldom consider impacts on insect pests, despite the damages that result directly from pest infestations and indirectly from pesticides applied to reduce pest damage (Rosenzweig et al. 2014). It's predicted that the insect pests are expected to differ in their response to increasing temperatures geographically and among crops (Lehmann et al. 2020).

Interaction between the temperature, physiology and demography of insects to project the upcoming impact of insects on crop production was well established by Jamieson et al. (2012) which helps to understand the complex climate-mediated effects on plant-insect and multitrophic level interactions as well as the roles of plant eco-physiological processes in driving both bottom-up and top-down controls. It was also estimated that pest-related changes in yields of the principal grain crops such as maize, rice and wheat, which collectively account for $42 \%$ of direct calories taken by humans globally (Deutsch et al. 2018). The information regarding yield losses due to insect pests on crops like rice is very limited and also demonstrated the urge for the development of pest management practices. Herbivorous insects destroy nearly one fifth of the crop production on the planet annually (Oerke 2006). The most important potential reason for proliferation of pests is the creating manmade habitats, i.e., agro ecosystems that fulfill human 
food requirements, where crops are selected for their huge size, high yield, nutritious value, and gathered in a confined area (Rembiałkowska 2007).This does not just suffice human demand but provides a highly conducive environment for herbivorous insects at the same time. Artificial crop selection methods made it possible to meet the demands of human consumption, but on the flip side it was subjected to be conducive for infestation of insect pests. For instance, infestation by khapra beetle (Trogoderma granarium Everts) larvae in grain kernels has negative effect on mineral composition, existing carbohydrates, protein, starch digestibility and bioavailability. The spoilage of kernels is more with the contamination of T. granarium body parts than consumption. Consumption of some of these contaminants in food may cause serious health issues (Athanassiou et al. 2019). Quantitative information on yield losses due to pests is vital to the development of sound pest management practices. It is therefore surprising to see how limited our information is today in the case of rice, the most important food crop worldwide.

\section{Pros and cons of existing tools of insect pest management Physical methods}

Farmers follow several cultural, mechanical, chemical, biological, botanical, genetic and regulatory practices to control the insect pests. In physical method, the insect pests were dislodged by spraying the plant with the water which knocks off aphids and mites, and however this is mostly in the case of household pests. The larvae from the bagworm can be picked off from the infested plant (Fields and Muir 2018). Well-known methods like traps are used to remove apple maggots, corn borers, fruit flies, bag worms, corn earworms, and peach tree borers through physical and/ or chemical-based traps (Wojtkowski 2010). Plant replacement technique was used to reduce the circulation and reduced many disease problems (Banks and Fields 1995). The two rational ways of controlling insect pests include living organisms that can kill the pest and the second incorporation of naturally occurring biochemicals that are harmful to the pest yet often are harmless to the consumers and the ecosystem. The insect pests are attacked by natural predators that are advantageous to the landscape. These beneficial insects often exist in the landscape naturally, but they also can be introduced. "Beneficials" may be predators or parasitoids. One common example of a beneficial predator is the lady beetles. Both the larvae and adult lady beetles prey on aphids and other soft-bodied insects. Other predators include lacewings, spined soldier bugs, flower flies, and spiders. Parasitoids live on and often kill their host. Some parasitic wasps use caterpillars, whiteflies, aphids, and soft scales as hosts. An example of an organism that possess a naturally occurring biochemical is the bacterium $B t$. Bt produces insecticidal proteins that are poisonous to specific group of insects, yet harmless to other organisms. $B t$ can be sprayed on plants and when the sensitive/susceptible insect pest feeds on the culture sprayed on the plant, protein gets ingested into the larvae and the larvae get killed (Mishra et al. 2017).

\section{Chemical methods}

Conventional chemicals are the primary go-to method of control and are often the most effective means of control. However, it should not be looked upon as the only method of control, as it can create selection pressure leading to resistance problems in pests which severely affects the sustainability of chemical methods. To use these chemicals to the fullest and have the greatest effect, chemicals need to be applied on a specific part of the plant when the pest is most vulnerable. Always chemical controls are to be applied according to instructions on the label. In many cases, environmentally safe pesticides such as horticultural oil or insecticidal soap are effective choices (Oerke 2006). However, applications must be timed carefully to have the greatest effect on the pest insect population. Because they have no residual activity after they have dried, soaps and oils are usually the option as they are the least disruptive to populations of beneficial organisms (Khan et al. 2008). The label on every pesticide formulation displays a warning sign like caution, warning, danger which indicates the level of toxicity of the chemical. These signs help to choose the least hazardous material among the effective alternatives. For the most landscape pests, it's needed to consider pesticides in only the first two categories. Some pesticide formulations can be applied only by applicators with special training and who are certified by the state's department of agriculture.

\section{Biological methods}

Biological methods of pest control can be an additional pest control tool especially when chemical methods of eradicating the insect pest have an unconstructive effect on the environment. In order to minimize the adverse effects on the environment, Sterile Insect Technique (SIT), which involves mass-rearing and releases of sterile insects is used for pest control. Sterile males must compete with wild males and reduce reproduction by wild females; in some cases the goal is eradication and in other programs it is to suppress pests. Ultimately, the goal is to reduce crop damage or transmission of insect-vectored diseases (Hoy 2003). SIT programs were highly effective in eradication of the screwworm (Cochliomyia hominivorax Coquerel) in North and Central Americas, and the Mediterranean fruit fly (Ceratitis capitata Wiedemann) 
in Florida and other locations (Alphey 2016). Large numbers of insects were sterilized by irradiation at unavoidable cost (Hoy 2003). In most of the cases, males were released involving sex-separation which is a complicated process. Both the difficulties of cost and sex separation can be prevented by using engineered strains carrying a dominant, repressible, lethal gene or genetic system (Alphey 2002). The chemical pesticides are substituted by the microbial insecticides, their usage is constrained to kill a narrow spectrum of insect species. Thus, making $B t$, a soil-borne bacteria, as a right choice, since long back to control the insect pest to overcome effects of synthetic chemical insecticides (Gupta and Dikshit 2010).

\section{Plant toxic proteins with insecticidal properties Lectins}

Lectins are proteins extensively found in nature produced by plants and other organisms including mammals. These are of non-immune origin that possesses one non-catalytic domain that specifically and reversibly binds to mono- or oligosaccharide (Macedo et al. 2015). These are multivalent so that agglutinate cells bind to the brushborder membrane of the insect's intestinal epithelial cells or, in the case of chitin-binding lectins, to the peritrophic membrane. The other way of toxicity is to bind to the two glycosylated digestive enzymes, particularly effective against the sap sucking; Hemiptera, Coleoptera, Lepidoptera and Homoptera (Chougule and Bonning 2012). Though activity of the lectin GNA (Galanthus nivalis agglutinin; GNA) from the snowdrop plant (Galanthus nivalis) against aphids, sap-sucking insects was demonstrated, harmful effects of GNA present in transgenic potatoes given raw as feed to rats showed an evidence to screen lectins more consistently in future (Ewen and Pusztai 1999; Macedo et al. 2015).

\section{Ribosome-inactivating proteins}

Ribosome-inactivating proteins (RIPs) are capable of enhancing plant resistance to insect pests such as lepidopterans (Dowd et al. 2006), coleopterans (Kumar et al. 1993) and dipterans (Shahidi-Noghabi et al. 2008). The insecticidal activity of the RIPs can be demonstrated by feeding the insect pests with artificial diet incorporated by RIPs. For example, the feeding of tobacco aphid (Myzus nicotianae Blackman) on leaves from transgenic tobacco plants overexpressing SNA-I retarded the growth and reduced the fecundity and adult survival (Shahidi-Noghabi et al. 2008). In addition, an artificial diet added with a different type-I RIPs also reduced the fecundity and survival of velvet bean caterpillar (Anticarsia gemmatalis Hübner), beet armywarm Spodoptera exigua (Hübner) and fall armywarm (Spodoptera frugiperda J.E. Smith) (Bertholdo-Vargas et al. 2009). Recent studies have suggested that type-I and type-II RIPs from apple (Malus domestica Borkh) have a strong aphicidal activity. The nymphal survival of aphids (M. nicotianae) in apples was greatly reduced by the artificial diet included with the purified recombinant proteins for type-I RIPs and type-II RIPs (Bolognesi et al. 2016).

\section{Bacillus thuringiensis}

$B t$ is a Gram-positive spore-forming bacterium that produces parasporal crystal proteins encoded by the $c r y$ or cyt genes, toxic to many insect species. The 30\% dry weight of the spore is represented by the parasporal crystal proteins (Mishra et al. 2017). Bt is more or less exclusively active against larval stages of different insect orders and kills the insect by disruption of the midgut tissue followed by septicaemia (Raymond et al. 2010). It consists of one or more pro-toxin species weighing about $160 \mathrm{kDa}$. The proteolyzed pro-toxins are converted into peptides, weigh up to $55 \mathrm{kDa}$ to $70 \mathrm{kDa}$ are predominantly toxic to lepidopteran, dipteran, or coleopteran insects (PardoLopez et al. 2013).

The first $\delta$-endotoxin coding gene was sequenced in 1985 (Schnepf and Whiteley 1985). Till date, 806 cry genes that code for Cry proteins were identified, which are usually located on the large plasmid (Palma et al. 2014). Most of the Cry proteins possess insecticidal activity and are exploited for the control of insect pests primarily in agriculture. Some of the recent studies have reported unique Cry proteins which are noninsecticidal, but have the ability to kill human cancer cells (Ohba et al. 2009). These cytotoxic proteins called Parasporins are mainly classified into six groups according to the homology of amino acid sequence by the Committee of Parasporin Classification and Nomenclature (PS1 through PS6).Human cancer cells from diverse origin illustrate cytocidal activity with the six parasporins with Cry numbers Cry31A, Cry41A, Cry45A, Cry46A, Cry63A and Cry64A (Ohba et al. 2009). In addition to the $\delta$-endotoxins, various isolates of $B t$ produce proteins such as vegetative insecticidal proteins (Vip) and secreted insecticidal proteins (Sip) that are secreted into the medium during the vegetative growth phase and have been found to have insecticidal properties against pests (Estruch et al. 1996). Bt also produces other potential insecticidal toxins like non-proteinaceous $\beta$-exotoxins, which are active against insect pests (Li et al. 2014).

\section{Bacillus thuringiensis toxin nomenclature}

In 1993, a committee was established in order to revise the nomenclature of $\delta$-endotoxins of $B t$, formerly devised in 1989 by (Höfte and Whiteley 1989). The modern classification of these $\delta$-endotoxins was completely based on the identity of the amino acid sequence (Xu et al. 2014). 
This systematic nomenclature helps the researchers to avoid the bioassay of every novel protein that is identified and ranked with close proximity. The original nomenclature has biological specificity. In the previous system, toxins and their corresponding genes were denoted in Roman numerals namely CryI for lepidopterans, CryII for coleopterans and dipterans, CryIII for coleopterans; and CryIV toxins specific to dipterans were illustrated in the previous classification. In the present classification Roman numerals have also been exchanged for Arabic numerals in the primary rank (e.g. CryIIIA became Cry3A) (Kaur and Allam 2006) (Fig. 1).

According to the pair wise amino acid identity, every novel toxin is given a four- rank name. In this new system of nomenclature, no implications were made according to the structure, host range or even mode of action of the newly identified toxins. Arabic numerals are given the first and fourth rank, upper- and lower-case alphabets were used for second and third ranks. In this manner, proteins sharing less than $45 \%$ pairwise identity are assigned a different primary rank. A completely new toxin might therefore, be assigned the name Cry76Aa1. To be more convenient enough it is proposed that the quaternary rank is an option and it gives the variation among proteins that are less than 5 and $95 \%$ alike in the protein sequence and is only used for elucidation. To make a note of quaternary ranks are allotted to all independently sequenced toxin genes, therefore even though in reality that several toxins encompass varied quaternary ranks - they could in fact be identical. This nomenclature in applied to $\delta$-endotoxin proteins (encoded by the $c r y$ genes) and cytotoxic proteins (encoded by the $c y t$ genes) and a class of insecticidal proteins secreted during the vegetative phase includes vegetative insecticidal proteins

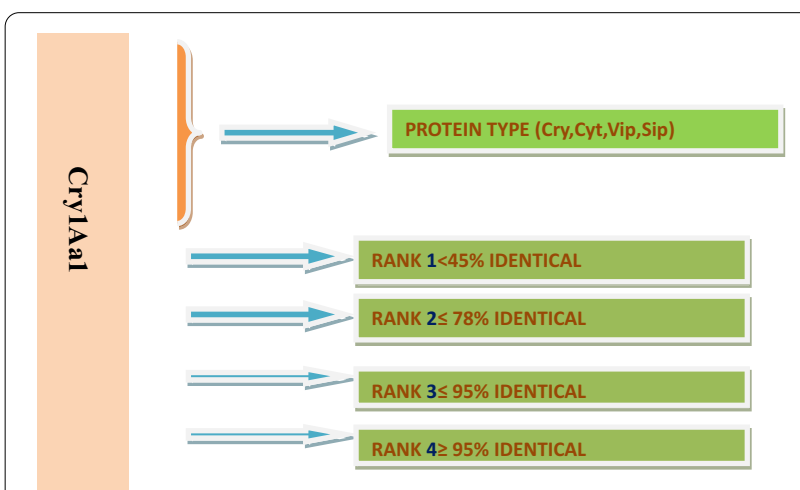

Fig. 1 An outline image of the present nomenclature system employed by the Bacillus thuringiensis toxin Nomenclature Committee for $\delta$-endotoxins and other toxins. The above image illustrates the Cry toxins with four ranked systems assigned by the percentage of amino acid similarity

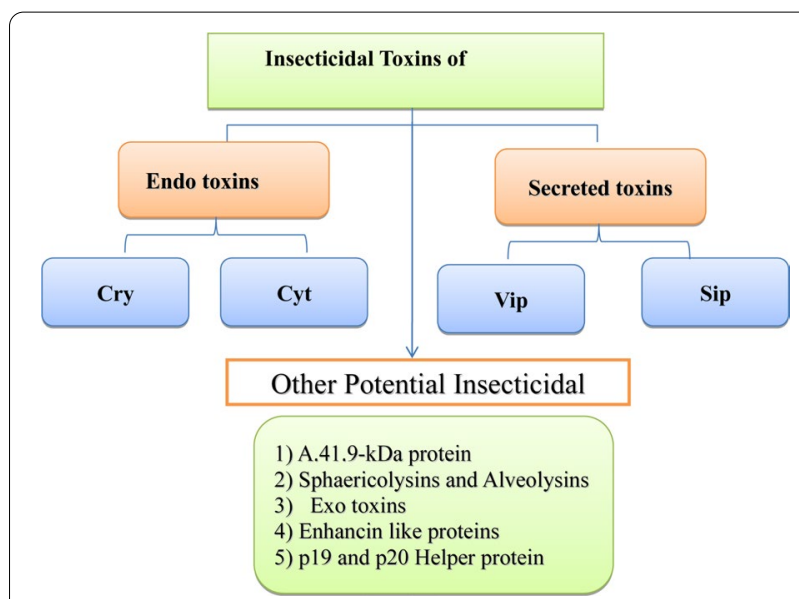

Fig. 2 A summarized illustration of the different Bacillus thuringiensis toxins produced during its vegetative and sporulation phase. The two different $\delta$-endotoxins, Cry (Crystal proteins) and Cyt (Cytotoxic proteins) are produced during sporulation and the other two secreted proteins, Vip (vegetative insecticidal proteins) and Sip (secreted insecticidal proteins) are produced during vegetative phase. The list of five other potential insecticidal toxins like A.41.9-kDa protein, Sphaericolysins and Alveolysins, $\beta$ Exotoxins, Enhancin like proteins, p19 and p20 Helper protein were also listed in the diagram

(vip) and secreted insecticidal protein (sip) (Crickmore et al. 2018). There are other potential insecticidal toxins discussed in brief below (Fig. 2).

\section{Cry toxins (cry genes)}

Currently more than 800 cry genes were classified into 75 classes of $\delta$-endotoxins based on the amino acid sequence similarities. These classes consist of several subclasses i.e., $\operatorname{cry} 1 A, \operatorname{cry} 1 B$...cry $1 Y$ ) which are subdivided into subfamilies or variants (cry1Aa, cry1Ab, cry1Ac, etc.). The genes included in the class had $45 \%$ similarity to each other. A restricted spectrum of activity can be observed by specific cry gene products limited to the larval stages of a small number of species. Updated list of $\delta$-endotoxin genes can be found at http://www.lifesci.sussex.ac.uk/ home/Neil_Crickmore/Bt/intro.html (Crickmore et al. 2020).

The identity of these Cry proteins has nowhere in relation to its spectrum of activity. For instance, the genes $84 \%$ identical to each other like $c r y 1 \mathrm{Aa}$ and $c r y 1 \mathrm{Ac}$ proteins among which only cry $1 \mathrm{Aa}$ is toxic to silkworm (Bombyx mori Linnaeus) (Atsumi et al. 2005).On the other hand,cry3Aa and cry7Aa genes 33\% identical to each other show toxicity against the Colorado potato beetle (Leptinotarsa decemlineata Say) (Lichtfouse et al. 2009). The typical illustration of a bacterium with this protein pattern is Bt subsp. israelensis, used all over the world as commercial preparations against dipteran larvae (Cantón et al. 2011). However, other than this set of 
proteins, in some cases, other complementary proteins such as Cry1 and Cry2 have been detected that enhance the toxic effect against Diptera (Ben-Dov et al. 1997). Some of Cry toxins i.e., Cry5, Cry6, Cry12, Cry13, Cry14, Cry21 protein classes are inactive against insects but show toxicity against invertebrates such as nematodes (Palma et al. 2014). More recently, binary toxins from $B t$ designated as Cry34Ab1/Cry35Ab1, active against various coleopteran insect pests of the Chrysomelidae family have also been characterized. In spite of their little homology with the other members of the Cry toxins, binary toxins were assigned a Cry designation. The Cry34A and Cry35A are $14-\mathrm{kDa}$ and $44-\mathrm{kDa}$ proteins, respectively, that function as binary toxins showing activity on the western corn rootworm (Diabrotica virgifera virgifera LeConte) (Ellis et al. 2002). Lepidopterans usually consume toxins through ingestion. Bt toxins classified and studied with insecticidal activity in this group are Cry1, Cry2, Cry9, and Cry15. However, the toxins viz.,Cry1, Cry2, and Cry9 groups were reported with insecticidal activity to velvet bean caterpillar (Anticarsia gemmatalis Hübner) (Bel et al. 2019).

Cry proteins are not only insecticidal but some of the Cry proteins of $B t$ strains B622 and B626 exhibited their toxicity on human pathogenic protozoan Trichomonas vaginalis and also produces lectin-like effect on rabbit erythrocytes (Palma et al. 2014). However, it did not show any insecticidal effect against the lepidopteran insect diamondblack moth (Plutella xylostella Linnaeus) and the dipteran London underground mosquito (Culex pipiens Molestus). The cry genes expressed in genetically modified (GM) crops like cry1Aa and cry $1 \mathrm{Ca}$ showed synergism against tobacco budworm (Heliothis virescens Fabricius), sugarcane stalk borer (Diatraea saccharalis Fabricius) and fall armyworm (Spodoptera frugiperda J. E. Smith) (Lemes et al. 2014). $B t$ Cry toxins have shown their toxicity against Asian tiger mosquito (Aedes aegypti Skuse) (Crickmore et al. 1998) and Bt subsp. israelensis to blood worm (Chironomus tepperi Skuse) (Hughes et al. 2005). According to (Yamagiwa et al. 2001), larvae tested on northern house mosquito (Culex pipiens Linnaeus) hasn't shown any toxicity against individual Cry protoxin, but the toxins turned active when larvae were exposed to two toxins together. This shows that the toxicology of the Cry proteins depends upon the formation of active toxin complex. The activity of $B t$ Cry toxins may differ widely depending upon Cry protein intake by herbivores and may be related to time, location, and amount of expression of the toxin in the plant (Devos et al. 2012). A new B. thuringiensis subsp. Galleriae producing Cry8Da has been commercialized recently which is active against coleopterans. The efficacy of this $B t$ product has been tested against the Alfalfa weevil (Hypera postica Gyllenhal) shown up to $40 \%$ reduction in number (Shrestha et al. 2018). The $B t$ toxins were termed to be versatile as they show undesirable activities such as haemolytic activity described for Cry15A toxin (Estruch et al. 1996). The Cry toxins also exhibit antibacterial activity which can hamper cloning and/or adequate expression (e.g., the three-domain toxins Cry13A and Cry14A) (Wei et al. 2003). Bt subsp., displayed antibacterial activity upon proteolytic activation against species of the anaerobic Gram-positive genus Clostridium and to an archaeal species (Yudina et al. 2007). Nevertheless, several Cry toxin genes have been incorporated into transgenic crops, providing an effective way to control insect pests in agriculture and lowering the worldwide use of field-applied chemical pesticides. The incorporation of $B t$ toxins saved up to US $\$ 30$ per ha through $70 \%$ cutback in the usage of insecticides and also tremendous increase in the yield up to $80-87 \%$ (Qaim 2009). Other Cry and Cyt-like proteins have also been reported to be bactericidal (Yudina et al. 2007).

\section{Structural features of crystal proteins}

The microscopic observation of the $B t$ under the phase contrast displays one or more crystalline inclusion (parasporal crystal) bodies during the sporulation of its growth cycle (Bechtel and Bulla 1976). These crystalline inclusions, for example, are synonymously called insecticidal crystal proteins (ICPs), Cry toxins or $\delta$-endotoxins. These parasporal crystals consist of proteins, which exhibit highly toxic insecticidal activity. On the other hand, actively growing cells lack the crystalline inclusions, so that they are not toxic. The $\delta$-endotoxins fall into two categories; Cyt and Cry. These two types of $\delta$-endotoxins do not share significant sequence homology, although, both seem to work through pore formation that leads to cell lysis and irreversible damage of the insect midgut (Chang et al. 1993). The three dimensional structures of the four $\delta$-endotoxins (Cry1, Cry2, Cry3and Cyt2A) were resolved by X-ray crystallography (Grochulski et al. 1995). The Cry1, Cry2, and Cry3 are remarkably similar, each of them consisting of three domains. The $\mathrm{N}$-terminal Domain I consists of seven $\alpha$-helices with a central core helix surrounded by six amphipathic helices. Domain II consists of three $\beta$-sheets with three-fold symmetry and the conformation is called 'Greek Key'. The C-terminal, domain III, consists of two anti-parallels of $\beta$-sheets in a 'jelly-roll' formation. Each domain of the Cry toxin has a role in the mode of action of the toxin i.e., Domain I is involved in membrane insertion and pore formation, Domains II and III are involved in receptor reorganization and binding (De Maagd et al. 2001). 


\section{Action mechanism of insecticidal cry toxins}

$B t$ produces crystal proteins during their sporulation which are toxic to the host and also show specificity. Consequently, each type of Cry protein is capable of toxins to one or more particular insect species. In contrast to the chemical pesticides crystal proteins do not affect many beneficial insects, plants and animals including humans due to its specific toxicity. The specificity of these insecticidal crystal proteins (ICPs) derives from their mode of action (Gill et al. 1992). The crystals produced during the sporulation of $B t$ consist of the ICPs which exist as protoxins. Following the ingestion of parasporal crystals by the susceptible insect pest, these crystals are dissolved in alkaline conditions ( $\mathrm{pH} 10-12)$ of the midgut of susceptible insect pest, producing 130 to $135 \mathrm{kDa}$ protein chains called protoxin. The gut proteases truncate the protoxins into actual toxic fragments of $60-65 \mathrm{kDa}$ (Höfte and Whiteley 1989). Thus, the activated toxin binds to the specific receptors of the larval mid-gut epithelia. Upon binding of the activated toxins, pores are created in the cell membrane. The formation of pore triggers off the osmotic shock and disturbs the ion channels. Consequently, the cell membrane breaks down, paralysis arises and as a result, the insect stops feeding and dies from starvation. Bt subsp. israelensis is highly toxic to different Aedes, Culex and Anopheles mosquito species that acts as vectors of several human infectious diseases (including chikugunya), produces crystal inclusions composed of Cry4Aa, Cry4Ba, Cry10Aa, Cry11Aa, Cyt1Aa and Cyt2Ba toxins (Fernández-Luna et al. 2010). As mentioned previously, the mosquitocidal active Cry proteins Cry11Aa, Cry4A and Cry4B share similar structures with the lepidopteran active toxin Cry1Aa suggesting a similar mode of action of these Cry proteins in mosquitoes (Dai and Gill 1993).

The Cry toxins produced by $B t$ have two different models. The most studied is the classical model also known as sequential binding model and the recent model is Signaling pathway or alternative mode of Cry toxins. In both the models after the ingestion of Cry toxins, they get dissolved in the insect midgut at alkaline $\mathrm{pH}$ forming an activated Cry toxin. These activated Cry toxins are monomers formed by the proteolysis at N-\& C-terminal ends by trypsin and chymotrypsin like proteases of the insect midgut (Bravo et al. 2007). The major role in receptor binding is played by the $C$ terminal end of the Cry toxin. Till date different insect midgut receptors including $\mathrm{ABC}$ transporters, glycophosphatidylinositol (GPI) anchored alkaline phosphatases (ALP), cadherin like proteins (CADR), GPI anchored aminopeptidases (APN) were identified as essential for activation of Cry toxins (Yudina et al. 2007). The cleaved Cry toxin oligomerizes to form pre-pore complex, which binds to the GPI anchored receptors and leads to pore formation through membrane insertion which in turn damages the midgut epithelium leading to the death of pest insect larvae. The acceleration of intracellular apoptotic pathway after the attachment of Cry toxin to the Cadherin receptors directing to the cell destruction damages midgut epithelium leads to larval death (Heckel 2020).

\section{Cyt toxins}

Apart from Cry proteins among $\delta$-endotoxins another significant insecticidal protein are Cyt (cytotoxic) proteins, coded by cyt genes in $B t$. The predominant specificity to dipterans and its cytolytic (hemolytic) activity makes the Cyt proteins different from that of Cry proteins. Cyt1Aa and Cyt2Ba showed three-dimensional structures with a single domain and of three-layer alphabeta proteins (Palma et al. 2014). The Cyt1Ca protein encoded by the pBtoxis plasmid of $B t$ subsp. israelensis different in having a further domain with homology to the carbohydrate binding domain of ricin, attached to the C-terminal end of the Cyt domain but no larvicidal or hemolytic activity has been observed with this toxin. Cytotoxic proteins identified till date could only be kept in three different families Cyt1, Cyt2 and Cyt3; with primary rank acknowledged in the $B t$ Toxin Nomenclature Committee which are lethal mostly against some mosquitoes and black flies. A wide range of toxic activity is observed in insects of Diptera, Lepidoptera and Coleoptera with the cyt genes present the diverse strains of $B t$ subsp., e.g., subsp. morrisoni (Guerchicoff et al. 2001). The Cyt2C protein showed a significant toxicity against nematodes (Rhabditida) and cancer cells. The Cyt proteins also play a vital role in insect resistance management by synergizing the insecticidal activity of other Cry or Vip3 toxins in some insect species. For instance, cotton leaf beetle (Chrysomela scripta Fabricius) pest is controlled by Cyt1Aa toxin and this toxin also inhibits the resistance of Cry3Aa (Federici and Bauer 1998). In the same way, Cyt1Aa is competent to hold back resistance to Cry 4 and Cry11Aa toxins in larvae of laboratory selected southern house mosquito (Culex quinquefasciatus Say) populations (Soberón et al. 2013). The Cyt proteins bind to Cry proteins to show synergism for instance binding of Cry11Aa to Cyt1Aa aids in cooperation of oligomerization of Cry11Aa toxin and pore formation. Moreover, toxins Cyt1Ab and Cyt2Ba from Bt subsp. medellin and subsp. israelensis enhanced the insecticidal activity of Lysinibacillus sphaericus (Bacillus sphaericus) against A.aegypti and resistant C.quinquefasciatus larvae (Soberón et al. 2013). Cyt1Aa demonstrated to have a synergistic activity, when combined with Mtx1 toxin from $L$. sphaericus, against $C$. quinquefasciatus. Two different modes of action have been proposed for the Cyt 
group of proteins: one suggests a pore-formation model whereas the other supports a less specific detergent action mechanism (Palma et al. 2014). For toxins like Cyt1Aa, with a typical cytolysin fold and a specific hemolytic pattern that differs from ionic and non-ionic detergents, a pore-forming mechanism was further suggested.

\section{Secreted toxins}

Vip

Some strains of $B t$ produce proteins during their vegetative growth phase into the growth medium, was found to have insecticidal properties against a number of insects, extending the overall host range of this bacterium. These insecticidal proteins include vegetative insecticidal proteins (Vip) and secreted insecticidal protein (Sip) and do not share any sequence or structural homology with the Cry toxic proteins. These secreted proteins had a specific conserved signal peptide sequence that are commonly cleaved before or after the secretion process is completed. At present, the $B t$ Toxin Nomenclature Committee has classified Vip proteins into four different families namely: Vip1, Vip2, Vip3 and Vip4 based on the amino acid sequence similarity. Among these Vip toxins, Vip1 and Vip2 act as binary toxins exhibiting toxicity against insects of Hemiptera and Coleoptera orders. While Vip3 proteins have no sequence and structural similarity with either Vip1 or Vip2 and are toxic to lepidopteran insects. Intriguingly, studies showed that the insecticidal mode of action of Vip3 toxins resembles with that of the Cry proteins. The target host insect for the Vip4 family insecticidal proteins remains to be identified (Chakroun et al. 2016).

\section{Sip}

The secreted insecticidal protein (Sip) constitutes one member Sip1Aa1 demonstrated toxicity against coleopteran larvae till 2017 (Fernández-Chapa et al. 2019). A recent study in China reported Sip1Ab gene from a native $B t$ strain QZL38 and its insecticidal activity against Colaphellus bowringi Baly (Coleopteran) (Sha et al. 2018). Sip proteins were initially isolated from supernatants of the $B t$ strain EG2158 and was as Sip1Aa1. The extent of sip1Aalgene is $1104 \mathrm{bp}$ and it encodes 367 amino acid protein and $\sim 41 \mathrm{kDa}$. Sip1Aa1 exhibits typical predicted Gram-positive consensus secretion signal 30 amino acids long. However, the protein was found $\mathrm{N}$-terminally processed, with its first 43 amino acids eliminated by active proteases present in the culture medium. It demonstrated little but considerable match to the $36-\mathrm{kDa}$ Mtx3 mosquitocidal toxin (a member of the ETX_MTX2 family of toxins) from L. sphaericus. This homology toxins strongly recommends that Sip1Aa1 toxicity possibly be caused by pore formation, but its mode of action remains unknown (Palma et al. 2014). Sip1Aa1 is lethal for Colorado potato beetle (Leptinotarsa decemlineata) (Coleoptera: Chrysomelidae) and inhibits growth of spotted cucumber beetle (Diabrotica undecimpunctate Howardi) (Coleoptera:Chrysomelidae) and Western corn rootworm (Diabrotica virgifera virgifera) (Palma et al. 2014). The only protein reported till 2017 is Sip1Aa1 with 90\% homology and the recent novel protein Sip1Ab identified in 2018 showed insecticidal activity towards Coleopterans (Sha et al. 2018).

\section{Insect resistance to $B t$}

The pests often become resistant to the $B t$ toxins if they are exposed to selection pressure by the toxin during several consecutive generations of the pest. The hindrance of resistance is essential to formulate a sustainable pesticide. There could be two possible ways to overcome the resistance mechanism. The primary strategy is to switch toxins hoping that the resistance besides first toxin is lost during the usage of the second toxin. The other strategy is to use several toxins altogether assuming that the development of resistance is quite impossible to the toxin combinations. These strategies only be productive against one of the toxins does not lead to resistance to the other toxins Lee et al. (1996) examined insecticidal activity of different toxins CryIAa, CryIAb, and CryIAc against lepidopteran pests like Lymantria dispar (gypsy moth) and Bombyx mori (silkworm) by force-feeding bioassays (Lee et al. 1996). The investigations demonstrated the synergism between the mixture of CrylAa and CryIAc in gypsy moth (L. dispar) pests whereas antagonistic effects were observed in CryIAa and CryIAb toxins. In the case of silkworm (B. mori) no synergistic effect was observed. The Cry toxins which were insensitive larvae to African cotton leaf worm (S. littoralis) were associated with the endochitinase ChiAII in order to increase the insecticidal effect even at low concentrations a synergistic toxic effect was observed. The interaction between the crystal proteins (Cry) and the vegetative insecticidal proteins (Vip) showed synergism when applied together. The toxins Cry9Aa and Vip3Aa exhibited high affinity in binding assay and showed elevated insecticidal activity against, the Asiatic rice borer (Chilo suppressalis Walker) (Wang et al. 2018).

Torres-Quintero et al. (2018) constructed hybridCyt1Aa mutants expressing the loop3 of crystal protein Cry1 Ab-domain II in varied demarcated regions of the Cyt1Aa toxin. The three hybrid variants of Cyt1Aa, Cyt3-Loop6, Cyt3-Loop7 and CycL3-Loop9 exhibited considerable binding to amino peptidase-N1, Alkaline phosphatase and Cadherin receptors in comparison to the control Cyt1Aa toxin. A significant toxicity was observed in two different lepidopteran larvae, tobacco 
hornworm (Manduca sexta Linnaeus) and diamondback moth (P. xylostella Linnaeus). Several combinations of Cry, Cyt and Vip proteins were constructed to hybrid toxins to overcome the resistance in pest control (TorresQuintero et al. 2018).

The insect pest Maruca pod borer (MPB), Maruca vitrata Fabricius (Lepidoptera; Crambidae) was inhibited by Vip3Ba protein both in vitro and in planta which was proposed to be complemented by cry genes in the development of Bt cowpeas resistant to MPB (Bett et al. 2017). According to Palma et al. (2014) Vip3C toxin had slight or no effect on many other lepidopteran pests. On the other hand, numerous studies have accounted for growthinhibiting effects of five different Vip3A proteins on selected lepidopteron pests (Hernández-Martínez et al. 2013). The insect- resistant corn Bt transgenic plants have set a case in point as a potential biotechnological commercial success story for the people. Moreover transgenic $B t$ cotton, maize and rice which are resistant to different lepidopteran pests are the present keys which are recognizable agricultural products with well documented insect virulence coupled with an extreme degree of antibiosis. Both lepidopteran and coleopteran pests were inhibited by the transgenic plants with an increased resistance range. As acknowledged earlier Vip3A proteins are excellent contenders for gene pyramiding in transgenic crops to combat development of resistance against the currently deployed genes. A synthetic plant-preferred codon-optimized novel vip3Aa44 was cloned into $\mathrm{pBI}$ $N A R$ plant transformation vector and tobacco explants were transformed with leaf disc co-cultivation method to evaluate toxicity of this gene against cotton bollworm (Helicoverpa armigera) and cotton leafworm (S. litura) were highly potential (Kalia and Kaur 2019).

\section{Plant secondary metabolites}

Plant secondary metabolites are a diverse and large number of specialized compounds which are not primarily useful in the growth and development of plants but are essential for the plant to survive. There are about 200,000 compounds which are mainly classified into three groups including flavonoids and allied phenolic and polyphenolic compounds, terpenoids and nitrogen-containing alkaloids and sulphur-containing compounds. These metabolites are toxic and deterrent to insect pests and few compounds function also indirect protection by attracting parasitic wasps or other natural enemies of insects feeding on plants. For instance, the two genes $z F P P$ and ShZIS coding enzymes that synthesized the sesquiterpene 7-epizingiberene were transferred from tomato (Lycopersicon esculentum) wild variety to cultivated variety expressed in trichomes, the plant showed enhanced protection against multiple insects (Douglas 2018).

\section{Arcelins}

Arcelins are insecticidal proteins, obtained from wild accessions of the common bean (Phaseolus vulgaris Linnaeus), with resistance against bruchid beetles. Arcelin protein purified from hyacinth bean (Lablab purpureus) had the ability to manage storage pest in cereals transformed with L. purpureus defense related gene (Janarthanan et al. 2008). The chemical composition of arcelin has many similarities with lectin including agglutinating activity. Till date, different allelic variants (designated Arc-1-7) of arcelin proteins have been described, with molecular weight in the range of $27-42 \mathrm{kDa}$. Of great interest are the insecticidal properties of arcelin variants toward bruchid pests and, in particular, their inhibitory effect on the larval development of the Mexican bean weevil (Zabrotes subfasciatus Boheman) (Karuppiah et al. 2018).

\section{RNA interference}

Designing insecticides that are different from the toxic proteins in terms of mode of action and specificity can be acquired through RNA interference (RNAi). The incorporated double-stranded RNA (dsRNA) particular to an essential gene of an insect pest into the cell turns out to be small interfering RNA (siRNA) molecules by dicer enzymes. Thus, the complementary mRNA is degraded by siRNA which guides Argonaute protein of the RNAinduced silencing complex (RISC) and in few occasions it also interferes with target mRNA. The crop protection in corn against the western corn rootworm and Colorado potato beetle in potato $L$. decemlineata was ensued through the orally delivered RNAi. In the United States, research is being carried out on processing of insecticidal RNAi against the western corn rootworm (Niu et al. 2017). Explicitly, SmartStax PRO (Monsanto) incorporates a dsRNA sequence in antagonistic to the $S n f 7$ gene of the western corn rootworm, stacked with cry3Bbland a herbicide resistance gene (Moar et al. 2017). The Snf7 protein is a class $\mathrm{E}$ vacuolar sorting protein, and it's down regulation resulted in perturbation to protein deubiquitination and autophagy in the insect midgut and fat body. More significantly, expression of dsRNA directed against suitable insect target genes in transgenic plants showed a protection against pests, opening the way for a new generation of insect-resistant crops (Niu et al. 2018).

\section{CRISPR-CAS9 system}

CRISPR-Cas9 (Clustered Regularly Interspaced Short Palindromic Repeats) systems have rapidly transitioned from intriguing prokaryotic defense systems to powerful and versatile bio molecular tools. The efficiency of this technology can be easily demonstrated in plants. Recent applications in bacteria have centered on multiplexed 
genome editing, programmable gene regulation, and sequence-specific antimicrobials, while future applications can build on advances in eukaryotes, the rich natural diversity of CRISPR-Cas9 systems, and the untapped potential of CRISPR-based DNA acquisition (Jinek et al. 2012). The model plant for CRISPR based systems is thalecress or Arabidopsis (Arabidopsis thaliana) (Bechtold and Pelletier 1998). In fact, this is an exception because in vitro transformation is the general methodology to produce stable transformed plants, which is a laborious process that requires suitable facilities and moreover, regeneration procedure in a varied species ranging from months to a year making it a time taking process (Busov et al. 2005). The genes that confer the resistance to antibiotics or herbicides (Miki and Mchugh 2004) are the key elements in transgene integration which also raises the concerns on biosecurity (Darbani et al. 2007). To remove these marker genes many alternative strategies were developed that are complex. Consequently, rapid exclusion of the transgene left a challenge in plant biotechnology after genome editing, particularly for prolonged life cycle crops and multiploidy, to avoid transgene position effects, minimize the probability of off-target mutation appearance, and to deliver consumers with plants free of the recombinant gene editing machinery (Yau and Stewart 2013).

CRISPR-Cas9 applications include a hassle in counter selection based on resistance marker genes as the plants without the transgene can't survive the selection and evaluating the transgene for more than two generations is an obligation. Arabidopsis thaliana was successfully tested for the presence of transgene prior to the germination with the expression of fluorescent proteins as selective markers (Stuitje et al. 2003). Moreover, it has also been used in combination with CRISPR in Arabidopsis (Gao et al. 2016). Despite its clear advantage, investigating on species such as tomato or rice is vital, and also need special requirements of in vitro transformation protocols (Zlobin et al. 2020).

\section{As a proof of concept}

Abbas et al. (2018b) has constructed a gene encoding IAA methyl transferase (IAMT) as a gene editing target in Arabidopsis (Arabidopsis thaliana), rice (Oryza sativa Linnaeus) and tomato (Solanum lycopersicum Linnaeus), given that loss of function results only in difficulty for hypocotyl reorientation after gravistimulation (Abbas et al. 2018a) and increased pollen tube growth rate (Abbas et al. 2018b), neither of which are traits that can bias our identification of mutations by direct observation unless specific tests are performed. The two plant species Arabidopsis (A. thaliana) and rice (O. sativa) were identified by a gene at 5955250 and os04g56950, respectively that encodes IAMT activity (Qin and Partridge 2005). On the other hand, in tomato two orthologues of IAMT1 Solyc07g64990 and Solyc12g14500 were identified by phylogenetic analysis. Therefore, tests were conducted on diverse editing strategies in each of the three selected species: targeting only one gene with one sgRNA (single guide RNA) in rice, simultaneously targeting two genes with two sgRNAs (in tomato), and targeting different regions of a single gene (in Arabidopsis) to evaluate the efficiency of the vectors when looking for multiple mutations and larger deletions. Preferably, the primary transformed plants include one copy of the transgene that would be segregated in the next generation in parallel to any CRISPR induced mutations in germline, thus it could use DsRED, basic red fluorescent protein visualization as marker of transgene existence to select non fluorescent seeds and subsequently look for mutations. Virus interference in plants can be impacted by molecular tools, the CRISPR/Cas system of genome editing (ChaparroGarcia et al. 2015). Ali et al. (2015) reported the CRISPR/ Cas9 approach for protection to plants against Gemini viruses. The plant viruses Gemini viruses species including BCTV (Beet curly top virus), TYLCV (Tomato yellow leaf curl virus), and MeMV (Merremia mosaic virus) displayed enhanced resistance against the given viruses through this system (Chaparro-Garcia et al. 2015).

\section{Commercial success}

Since 1995, several new traits and combinations of traits have been developed and marketed in cotton cultivars. In 1996, Bollgard cotton hit the market, which had a transgene from bacterium $B t$ producing Cry1Ac which is an endotoxin (Begemann 1996). Bollgard cultivars control major lepidopteron pests such as the tobacco budworm (H. virescens), the pink bollworm (Pectinophora gossypiella Saunders), and suppress populations of bollworm (Helicoverpa zea Boddie). In 1998, cultivars possessing both the Cry I Ac $B t$ endotoxin and the Roundup Ready technology, often referred to as stacked gene cultivars, were introduced (Kerby and Voth 1998). Until 2004, no new types of transgenic technologies were introduced for cotton. In 2004, second generation of transgenic cultivars commenced. Cultivars were introduced that made improvements in both $B t$ and glyphosate resistance technologies. Bollgard II, a genetic technology whereby two $B t$ endotoxins were expressed by the cultivar, had an enhanced spectrum of control of lepidopteran insect pests compared to the single-gene $B t$ cultivars. Bollgard II technology was commercially released in 2004 in cultivars that also expressed the RR technology (Jost et al. 2008). These stacked traits along with the refuge strategy slowed down the evolution 
of $B t$ resistance in bollworm for more time than predicted. In 2005, another two gene $B t$ technology were released by Dow Agrosciences. In 2006, an improved version of the Roundup Ready technology known as RoundupReady Flex (RF), was made commercially available (Murdock and Mullins 2006). The genetic event conferring glyphosate resistance in the RR technology only fully protects cotton fruiting forms if glyphosate was applied to cotton foliage before the 4 leaf stage (Pline et al. 2002). Roundup Ready Flex technology permits application of glyphosate over the top of cotton throughout the period of fruit set. In 2006, Bollgard II technology in conjunction with LibertyLink technology was introduced. Breeding procedures involved in the development of multi-stacked traits, some of the advantages and disadvantages associated with multi-stacked traits were detailed in Also, a list of multi-stacked traits, private industries who own them and the gene involved in each stack were detailed in Que et al. (2010).

In India, cotton (Gossypium hirsutum Linnaeus) and soybean (Glycine max Linnaeus) are the approved genetically modified crops. In 2014 GEAC (Genetic Engineering Appraisal Committee) approved 11 crops for the field trials which includes maize, rice, wheat, groundnut sorghum and cotton. A Moratorium was laid on Bt Brinjal in 2010 by the Indian Government which crippled the research on transgenic crops. The data generated by India was taken by the Bangladesh and 25,000 farmers cultivated $B t$ Brinjal and made it a success. USA, Brazil, Argentina, Canada, and India altogether have occupied 91\% of the global biotech crop area (Brookes and Barfoot 2017). According to ISAAA (The International Service for the Acquisition of Agri-biotech Applications), the USA has 203 GM crops approved with 21 variants, cultivating food crops like maize, soybean, canola, sugar beet, papaya, squash, potato, livestock feed like alfalfa and a commercial crop cotton in nearly 70.1 million hectares in USA, followed by Brazil, Argentina, Canada and India. The information from ISAAA proclaims that around 2.7 billion hectares of biotech tech crops planted since 1996. Malawi, Ethiopia and Nigeria have planted Bt cotton for the first time in 2019.

\section{Conclusions}

Integrated pest management combined with other control methods like chemical, physical and planting both $B t$ and non- $B t$ together is more effective. Moreover, new molecular techniques have to be applied in order to overcome insect pest resistance by merging RNAi to $B t$ may considerably delay resistance, especially in bollworm. Molecular tools like CRISPR-based gene drivers can be employed to extend the target genetic elements through large numbers of inhabitants in combination with Bttransgenic crops may lead to effective pest resistance management with ecofriendly methods.

\begin{tabular}{|c|c|c|c|c|}
\hline S. No & Event name & $\begin{array}{l}\text { Genes } \\
\text { incorporated }\end{array}$ & Source & Function \\
\hline 1 & BNLA-601 & CrylAc & $\begin{array}{l}\text { Bacillus } \\
\text { thuringien- } \\
\text { sis subsp. } \\
\text { kurstaki strain } \\
\text { HD73 }\end{array}$ & $\begin{array}{l}\text { Confers } \\
\text { resistance to } \\
\text { lepidopteran } \\
\text { insects by } \\
\text { selectively } \\
\text { damaging their } \\
\text { midgut lining }\end{array}$ \\
\hline 2 & $\begin{array}{l}\text { JK } 1 \text { TRADE } \\
\text { NAME }\end{array}$ & cry $1 A c \& n p t / I^{*}$ & $\begin{array}{l}\text { Bacillus } \\
\text { thuringien- } \\
\text { sis subsp. } \\
\text { kurstaki strain } \\
\text { HD73 }\end{array}$ & $\begin{array}{l}\text { Confers } \\
\text { resistance to } \\
\text { lepidopteran } \\
\text { insects \& allows } \\
\text { transformed } \\
\text { plants to } \\
\text { metabolize } \\
\text { neomycin and } \\
\text { kanamycin } \\
\text { antibiotics dur- } \\
\text { ing selection }\end{array}$ \\
\hline 3 & GFM Cry1A & $\begin{array}{l}\text { cry } 1 A b-A c \text { delta } \\
\text { endotoxin } \\
\text { (fusion protein) } \\
\text { nptll* uid }^{*}\end{array}$ & $\begin{array}{l}\text { synthetic } \\
\text { fusion gene } \\
\text { derived } \\
\text { from Bacillus } \\
\text { thuringiensis }\end{array}$ & $\begin{array}{l}\text { Confers } \\
\text { resistance to } \\
\text { lepidopteran } \\
\text { insects \& } \\
\text { produces blue } \\
\text { stain on treated } \\
\text { transformed } \\
\text { tissue, which } \\
\text { allows visual } \\
\text { selection }\end{array}$ \\
\hline 4 & MLS 9124 & $\begin{array}{l}\text { cry } 1 C \text { delta- } \\
\text { endotoxin }\end{array}$ & $\begin{array}{l}\text { synthetic } \\
\text { fusion gene } \\
\text { derived } \\
\text { from Bacillus } \\
\text { thuringiensis }\end{array}$ & $\begin{array}{l}\text { Confers } \\
\text { resistance to } \\
\text { lepidopteran } \\
\text { insects, specifi- } \\
\text { cally Spodop- } \\
\text { tera }\end{array}$ \\
\hline 5 & $\begin{array}{l}\text { Bollgard } \|^{\mathrm{TM}} \\
\text { Cotton }\end{array}$ & $\begin{array}{l}\text { cry } 1 A c \& \text { \& rry2Ab } \\
\text { nptl/* } \\
\text { uidA, aad* }\end{array}$ & $\begin{array}{l}\text { Bacillus } \\
\text { thuringien- } \\
\text { sis subsp. } \\
\text { kumamotoen- } \\
\text { sis \& } \\
\text { Bacillus } \\
\text { thuringien- } \\
\text { sis subsp. } \\
\text { kurstaki strain } \\
\text { HD73 }\end{array}$ & $\begin{array}{l}\text { Confers } \\
\text { resistance to } \\
\text { lepidopteran } \\
\text { insects by } \\
\text { selectively } \\
\text { damaging their } \\
\text { midgut lining }\end{array}$ \\
\hline 6 & $\begin{array}{l}\text { Bollgard }^{\mathrm{TM}} \\
\text { Cotton, }^{\text {, }} \\
\text { Ingard }^{\mathrm{TM}}\end{array}$ & $\begin{array}{l}\text { cry } 1 A c \& \text { cry2Ab } \\
\text { nptll* aad* }\end{array}$ & $\begin{array}{l}\text { Bacillus } \\
\text { thuringien- } \\
\text { sis subsp. } \\
\text { kurstaki strain } \\
\text { HD73 }\end{array}$ & $\begin{array}{l}\text { Confers } \\
\text { resistance to } \\
\text { lepidopteran } \\
\text { insects by } \\
\text { selectively } \\
\text { damaging their } \\
\text { midgut lining }\end{array}$ \\
\hline
\end{tabular}




\begin{tabular}{|c|c|c|c|c|}
\hline S. No & Event name & $\begin{array}{l}\text { Genes } \\
\text { incorporated }\end{array}$ & Source & Function \\
\hline 7 & $\begin{array}{l}\text { Intacta } \\
\text { Roundup }^{\mathrm{TM}} \\
\text { Ready }^{\mathrm{TM}} 2 \text { Pro }\end{array}$ & $\begin{array}{l}\text { cry } 1 A c \& \text { cp } 4 \\
\text { epsps* }\end{array}$ & $\begin{array}{l}\text { Bacillus } \\
\text { thuringien- } \\
\text { sis subsp. } \\
\text { kurstakistrain } \\
\text { HD73 }\end{array}$ & $\begin{array}{l}\text { Confers } \\
\text { resistance to } \\
\text { lepidopteran } \\
\text { insects by } \\
\text { selectively } \\
\text { damaging their } \\
\text { midgut lining, } \\
\text { conferring } \\
\text { increased } \\
\text { tolerance to } \\
\text { glyphosate } \\
\text { herbicide }\end{array}$ \\
\hline
\end{tabular}

The table gives information regarding genetically modified crops approved in India with $B t$ genes incorporated. Out of 11 approved GM crops 6 are cotton crops Gossypium hirsutum $L$ and rest 5 crops are Soybean Glycine max $L$ but Intacta ${ }^{\mathrm{TM}}$ Roundup Ready ${ }^{\mathrm{TM}} 2$ Pro is the only $B t$ gene incorporated crop. All genes confer resistance to lepidopteran pest, MLS 9124 confers resistance to lepidopterans. '“' are the marker/ reporter genes incorporated in the event crop. (Source: https://www.isaaa.org/gmapprovaldatabase/default. asp).

\section{Abbreviations}

Bt: Bacillus thruringiensis; SIT: Sterile Insect Technique; ICPs: Insecticidal Crystal Proteins; Cry: Crystal proteins; Cyt: Cytotoxic proteins; VIP: Vegetative Insecticidal Proteins; SIP: Secreted Insecticidal Protein; GPI: Glycophosphatidylinositol; ALP: Anchored Alkaline Phosphatases; CADR: Cadherin Like Proteins; APN: Aminopeptidases; MeMV: Merremia mosaic virus; TYLCV: Tomato yellow leaf curl virus; IAA: Methyl transferase; IAMT: IAA methyl transferase; CRISPR: Clustered Regularly Interspaced Short Palindromic Repeats; RISC: RNA-induced silencing complex; siRNA: Small interfering RNA; dsRNA: Double-stranded RNA; RNAi: RNA interference RNAi; MPB: Maruca pod borer.
\end{abstract}

\section{Acknowledgements}

Nil.

\section{Authors' contributions}

Conceptualization SK and USA, Writing - original draft preparation by SK, USA, KNM, SM, RV, CK, SHI. Writing - review and editing by all authors. All authors have read and approved the final manuscript.

\section{Funding}

Not applicable.

\section{Availability of data and materials}

Data sharing is not applicable to this article as no datasets were generated or analysed during the current study.

\section{Declarations}

Ethics approval and consent to participate

Not applicable.

\section{Consent for publication}

Not applicable.

\section{Competing interests}

The authors declare that they have no competing interests.

\section{Author details}

${ }^{1}$ Department of Biotechnology, SPSR Bhavan, Vikrama Simhapuri University, SPS Nellore 524 320, Andhra Pradesh, India. ${ }^{2}$ Krishi Vignan Kendra (KVK), ANGRAU, Nellore 524 004, Andhra Pradesh, India. ${ }^{3}$ Department of Tourism Management, Vikrama Simhapuri University, Nellore 524320, Andhra Pradesh, India. ${ }^{4}$ Graduate Research Assistant, Soil and Crop Science Department, Texas A\&M University, College Station 77843, USA.

Received: 20 May 2021 Accepted: 21 Auqust 2021

Published online: 02 September 2021

\section{References}

Abbas M, Hernández-García J, Blanco-Touriñán N, Aliaga N, Minguet EG, Alabadí D, Blázquez MA (2018a) Reduction of indole-3-acetic acid methyltransferase activity compensates for high-temperature male sterility in Arabidopsis. Plant Biotechnol J 16(1):272-279

Abbas M, Hernández-García J, Pollmann S, Samodelov SL, Kolb M, Friml J, Hammes UZ, Zurbriggen MD, Blázquez MA, Alabadí D (2018b) Auxin methylation is required for differential growth in Arabidopsis. Proc Natl Acad Sci 115(26):6864-6869

Ali Z, Abulfaraj A, Idris A, Ali S, Tashkandi M, Mahfouz MM (2015) CRISPR/Cas9mediated viral interference in plants. Genome Biol 16(1):238

Alphey L (2002) Re-engineering the sterile insect technique. Insect Biochem Mol Biol 32(10):1243-1247

Alphey L (2016) SIT 20: 21st Century genetic technology for the screwworm sterile-insect program. BMC Biol 14(1):80

Athanassiou CG, Phillips TW, Wakil W (2019) Biology and control of the khapra beetle, Trogoderma granarium, a major quarantine threat to global food security. Annu Rev Entomol 64:131-148

Atsumi S, Mizuno E, Hara H, Nakanishi K, Kitami M, Miura N, Tabunoki H, Watanabe A, Sato R (2005) Location of the Bombyx mori aminopeptidase N type 1 binding site on Bacillus thuringiensis Cry1Aa toxin. Appl Environ Microbiol 71(7):3966-3977

Banks HJ, Fields P (1995) Physical methods for insect control. In: Jayas D, White NDG, Muir WE (eds) Stored-grain ecosystems. Marcel Dekker, pp 353-407

Bechtel DB, Bulla LA (1976) Electron microscope study of sporulation and parasporal crystal formation in Bacillus thuringiensis. J Bacteriol 127(3):472-481

Bechtold N, Pelletier G (1998) In planta Agrobacterium mediated transformation of adult Arabidopsis thaliana plants by vacuum infiltration. Methods Mol Biol 82:259-266

Begemann B (1996) Bt cotton workshop: plans for introduction. In: Proceedings of the beltwide cotton conference, National Cotton Council, Memphis, TN, vol 1, p 164

Bel Y, Zack M, Narva K, Escriche B (2019) Specific binding of Bacillus thuringiensis Cry1Ea toxin, and Cry1 Ac and Cry1Fa competition analyses in Anticarsia gemmatalis and Chrysodeixis includens. Sci Rep 9(1):1-7

Ben-Dov E, Zaritsky A, Dahan E, Barak ZE, Sinai R, Manasherob R, Khamraev A, Troitskaya E, Dubitsky A, Berezina N (1997) Extended screening by PCR for seven cry-group genes from field-collected strains of Bacillus thuringiensis. Appl Environ Microbiol 63(12):4883-4890

Bensoussan N, Santamaria ME, Zhurov V, Diaz I, Grbić M, Grbić V (2016) Plantherbivore interaction: dissection of the cellular pattern of Tetranychus urticae feeding on the host plant. Front Plant Sci 7:1105

Bertholdo-Vargas LR, Martins JN, Bordin D, Salvador M, Schafer AE, De Barros NM, Barbieri L, StirpeC F, Carlini CR (2009) Type 1 ribosome-inactivating proteins-Entomotoxic, oxidative and genotoxic action on Anticarsia gemmatalis (Hübner) and Spodoptera frugiperda (JE Smith) (Lepidoptera: Noctuidae). J Insect Physiol 55(1):51-58

Bett B, Gollasch S, Moore A, James W, Armstrong J, Walsh T, Harding R, Higgins TJ (2017) Transgenic cowpeas (Vigna unguiculata L. Walp) expressing Bacillus thuringiensis Vip3Ba protein are protected against the Maruca pod borer (Maruca vitrata). Plant Cell Tissue Organ Culture 131(2):335-345

Bolognesi A, Bortolotti M, Maiello S, Battelli MG (2016) Polito Ribosomeinactivating proteins from plants: a historical overview. Molecules 21(12):1627 
Bravo A, Gill SS, Soberon M (2007) Mode of action of Bacillus thuringiensis Cry and Cyt toxins and their potential for insect control. Toxicon 49(4):423-435

Brookes G, Barfoot P (2017) Economic impact of GM crops: the global income and production effects 1996-2012. GM Crops Food 5(1):65-75

Burke JF, Thomas SM (1997) Agriculture is biotechnology's future in Europe. Nat Biotechnol 15(8):695-696

Busov VB, Brunner AM, Meilan R, Filichkin S, Ganio L, Gandhi S, Strauss SH (2005) Genetic transformation: a powerful tool for dissection of adaptive traits in trees. New Phytol 167(1):9-18

Cantón PE, Reyes EZ, De Escudero IR, Bravo A, Soberón M (2011) Binding of Bacillus thuringiensis subsp. israelensis Cry4Ba to Cyt1 Aa has an important role in synergism. Peptides 32(3):595-600

Chakroun M, Banyuls N, Bel Y, Escriche B, Ferré J (2016) Bacterial vegetative insecticidal proteins (Vip) from entomopathogenic bacteria. Microbio Mol Biol Rev 80(2):329-350

Chang C, Yu Y-M, Dai S-M, Law S, Gill S (1993) High-level crylVD and cytA gene expression in Bacillus thuringiensis does not require the 20-kilodalton protein, and the coexpressed gene products are synergistic in their toxicity to mosquitoes. Appl Environ Microbiol 59(3):815-821

Chaparro-Garcia A, Kamoun S, Nekrasov V (2015) Boosting plant immunity with CRISPR/Cas. Genome Biol 16(1):254

Chapman R (2009) Foraging and food choice in phytophagous insects. In: Hardege JD (ed) Chemical ecology. Eolss Publishers

Chougule NP, Bonning BC (2012) Toxins for transgenic resistance to hemipteran pests. Toxins 4(6):405-429

Crickmore N, Baum J, Bravo A, Lereclus D, Narva K, Sampson K, Schnepf E, Sun M, Zeigler DR (2018) Bacillus thuringiensis toxin nomenclature. http:// www.btnomenclature.info/ Accessed 27 Mar 2020

Crickmore N, Berry C, Panneerselvam S, Mishra R, Connor TR, Bonning BC (2020) A structure-based nomenclature for Bacillus thuringiensis and other bacteria-derived pesticidal proteins. J Invertebr Pathol. https:// doi.org/10.1016/j.jip.2020.107438

Crickmore N, Zeigler D, Feitelson J, Schnepf E, Van Rie J, Lereclus D, Baum J, Dean D (1998) Revision of the nomenclature for the Bacillus thuringiensis pesticidal crystal proteins. Microbiol Mol Biol Rev 62(3):807-813

Dai S, Gill SS (1993) In vitro and in vivo proteolysis of the Bacillus thuringiensis subsp. israelensis CryIVD protein by Culex quinquefasciatus larval midgut proteases. Insect Biochem Mol Biol 23(2):273-283

Darbani B, Eimanifar A, Stewart CN Jr, Camargo WN (2007) Methods to produce marker-free transgenic plants. Biotechnol J Healthc Nutr Technol 2(1):83-90

De Maagd RA, Bravo A, Crickmore N (2001) How Bacillus thuringiensis has evolved specific toxins to colonize the insect world. Trends Genet 17(4):193-199

Deutsch CA, Tewksbury JJ, Tigchelaar M, Battisti DS, Merrill SC, Huey RB, Naylor RL (2018) Increase in crop losses to insect pests in a warming climate. Science 361(6405):916-919

Devos Y, De Schrijver A, De Clercq P, Kiss J, Romeis J (2012) Bt-maize event MON 88017 expressing Cry3Bb1 does not cause harm to non-target organisms. Transgenic Res 21(6):1191-1214

Dhaliwal GS, Jindal V, Dhawan AK (2010) Insect pest problems and crop losses: changing trends. Indian J Ecol 37(1):1-7

Douglas AE (2018) Strategies for enhanced crop resistance to insect pests. Annu Rev Plant Biol 69:637-660

Dowd PF, Holmes RA, Pinkerton TS, Johnson ET, Lagrimini LM, Boston RS (2006) Relative activity of a tobacco hybrid expressing high levels of a tobacco anionic peroxidase and maize ribosome-inactivating protein against Helicoverpa zea and Lasioderma serricorne. J Agric Food Chem 54(7):2629-2634

Ellis RT, Stockhoff BA, Stamp L, Schnepf HE, Schwab GE, Knuth M, Russell J, Cardineau GA, Narva KE (2002) Novel Bacillus thuringiensis binary insecticidal crystal proteins active on western corn rootworm, Diabrotica virgifera virgifera LeConte. Appl Environ Microbiol 68(3):1137-1145

Estruch JJ, Warren GW, Mullins MA, Nye GJ, Craig JA, Koziel MG (1996) Vip3A, a novel Bacillus thuringiensis vegetative insecticidal protein with a wide spectrum of activities against lepidopteran insects. Proc Natl Acad Sci 93(11):5389-5394

Ewen S, Pusztai WA (1999) Effect of diets containing genetically modified potatoes expressing Galanthus nivalis lectin on rat small intestine. The Lancet 354(9187):1353-1354
Federici BA, Bauer LA (1998) Cyt1Aa Protein of Bacillus thuringiensis/s toxic to the cottonwood leaf beetle, Chrysomela scripta, and suppresses high levels of resistance to Cry3Aa. Appl Environ Microbiol 64(11):4368-4371

Fernández-Chapa D, Ramírez-Villalobos L, Galán-Wong L (2019) Toxic Potential of Bacillus thuringiensis: an Overview. Protecting rice grains in the postgenomic era. IntechOpen

Fernández-Luna MT, Tabashnik BE, Lanz-Mendoza H, Bravo A, Soberón M, Miranda-Ríos J (2010) Single concentration tests show synergism among Bacillus thuringiensis subsp. israelensis toxins against the malaria vector mosquito Anopheles albimanus. I Invertebr Pathol 104(3):231-233

Fields PG, Muir WE (2018) Physical control. Integrated management of insects in stored products. CRC Press, pp 195-221

Flores S, Saxena D, Stotzky G (2005) Transgenic Bt plants decompose less in soil than non-Bt plants. Soil Biol Biochem 37(6):1073-1082

Gao X, Chen J, Dai X, Zhang D, Zhao Y (2016) An effective strategy for reliably isolating heritable and Cas9-free Arabidopsis mutants generated by CRISPR/Cas9-mediated genome editing. Plant Physiol 171(3):1794-1800

Gill SS, Cowles EA, Pietrantonio PV (1992) The mode of action of Bacillus thuringiensis endotoxins. Annu Rev Entomol 37(1):615-634

Grochulski P, Masson L, Borisova S, Pusztai-Carey M, Schwartz JL, Brousseau R, Cygler M (1995) Bacillus thuringiensis CrylA (a) insecticidal toxin: crystal structure and channel formation. J Mol Biol 254(3):447-464

Guerchicoff A, Delécluse A, Rubinstein CP (2001) The Bacillus thuringiensiscyt genes for hemolytic endotoxins constitute a gene family. Appl Environ Microbiol 67(3):1090-1096

Gupta S, Dikshit AK (2010) Biopesticides: An ecofriendly approach for pest control. J Biopestic 3(1 Special Issue):186-188

Heckel DG (2020) How do toxins from Bacillus thuringiensis kill insects? An evolutionary perspective. Arch Insect Biochem Physiol 104(2):e21673

Hernández-Martínez P. Hernández-Rodríguez CS, Van Rie J, Escriche B, Ferré J (2013) Insecticidal activity of Vip3Aa, Vip3Ad, Vip3Ae, and Vip3Af from Bacillus thuringiensis against lepidopteran corn pests. J Invertebr Pathol 113(1):78-81

Höfte H, Whiteley HR (1989) Insecticidal crystal proteins of Bacillus thuringiensis. Microbiol Mol Biol Rev 53(2):242-255

Horsch RB, Fraley RT, Rogers SG, Sanders PR, Lloyd A, Hoffmann N (1984) Inheritance of functional foreign genes in plants. Science 223(4635):496-498

Hoy MA (2003) Insect molecular genetics: an introduction to principles and applications. Academic Press

Hughes PA, Stevens MM, Park HW, Federici BA, Dennis ES, Akhurst R (2005) Response of larval Chironomus tepperi (Diptera: Chironomidae) to individual Bacillus thuringiensis var israelensis toxins and toxin mixtures. J Invertebr Pathol 88(1):34-39

Jamieson MA, Trowbridge AM, Raffa KF, Lindroth RL (2012) Consequences of climate warming and altered precipitation patterns for plant-insect and multitrophic interactions. Plant Physiol 160(4):1719-1727

Janarthanan S, Suresh P, Radke G, Morgan TD, Oppert B (2008) Arcelins from an Indian wild pulse, Lablab purpureus, and insecticidal activity in storage pests. J Agric Food Chem 56(5):1676-1682

Jinek M, Chylinski K, Fonfara I, Hauer M, Doudna JA, Charpentier E (2012) A programmable dual-RNA-guided DNA endonuclease in adaptive bacterial immunity. Science 337(6096):816-821

Jost P, Shurley D, Culpepper S, Roberts P, Nichols R, Reeves J, Anthony S (2008) Economic comparison of transgenic and nontransgenic cotton production systems in Georgia. Agron J 100(1):42-51

Kalia V, Kaur S (2019) Efficacy of transgenic tobacco carrying synthetic plantpreferred codon-optimized novel VIP3AA44 Gene towards Helicoverpa armigera and Spodoptera litura. Indian J Entomol 81(2):325-331

Karuppiah H, Kirubakaran N, Sundaram J (2018) Genetic resources for arcelin, a stored product insect antimetabolic protein from various accessions of pulses of Leguminosae. Genet Resour Crop Evol 65(1):79-90

Kaur S, Allam US (2006) PCR-based cloning of a novel cry1 Ac gene from a Bacillus thuringiensis isolate recovered from stored cottonseeds. Biopestic Int 2:120-128

Kerby T R, Voth R (1998) Roundup ready: introduction experiences in 1997 as discussed in the Beltwide Cotton Production Conference Weed Management: Transgenics and new technologies panel. Paper presented at the Beltwide Cotton Conferences (USA)

Khan ZR, James DG, Midega CA, Pickett JA (2008) Chemical ecology and conservation biological control. Biol Control 45(2):210-224 
Kumar MA, Timm D, Neet KE, Owen WG, Peumans WG, Rao AG (1993) Characterization of the lectin from the bulbs of Eranthis hyemalis (winter aconite) as an inhibitor of protein synthesis. J Biol Chem 268(33):25176-25183

Lee MK, Curtiss A, Alcantara E, Dean DH (1996) Synergistic effect of the Bacillus thuringiensis toxins CrylAa and CrylAc on the gypsy moth, Lymantria Dispar. Appl Environ Microbiol 62(2):583-586

Lehmann P, Ammunet T, Barton M, Battisti A, Eigenbrode SD, Jepsen JU, Kalinkat G, Neuvonen S, Niemela P, Okland B (2020) Complex responses of global insect pests to climate change. Front Ecol Environ 18:141-150

Lemes ARN, Davolos CC, Legori PCBC, Fernandes OA, Ferre J, Lemos MVF, Desiderio JA (2014) Synergism and antagonism between Bacillus thuringiensis Vip3A and Cry1 proteins in Heliothis virescens, Diatraea saccharalis and Spodoptera frugiperda. PLoS ONE 9(10):e107196

Li G, Wang Y, Liu B, Zhang G (2014) Transgenic Bacillus thuringiensis (Bt) rice is safer to aquatic ecosystems than its non-transgenic counterpart. PLoS ONE 9(8):e104270

Lichtfouse E, Navarrete M, Debaeke P, Souchere V, Alberola C, Ménassieu J (2009) Agronomy for sustainable agriculture: a review. In: Lichtfouse E, Navarrete M, Debaeke P, Véronique S, Alberola C (eds) Sustainable agriculture. Springer, $\mathrm{pp}$ 1-7

Macedo MLR, Oliveira CF, Oliveira CT (2015) Insecticidal activity of plant lectins and potential application in crop protection. Molecules 20(2):2014-2033

Miki B, Mchugh S (2004) Selectable marker genes in transgenic plants: applications, alternatives and biosafety. J Biotechnol 107(3):193-232

Mishra PK, Bisht SC, Ruwari P, Subbanna ARNS, Bisht JK, Bhatt JC, Gupta HS (2017) Genetic diversity and functional characterization of endophytic Bacillus thuringiensis isolates from the North Western Indian Himalayas. Ann Microbiol 67(2):143-155

Moar W, Khajuria C, Pleau M, Ilagan O, Chen M, Jiang C, Price P, Mcnulty B, Clark T, Head G (2017) Cry3Bb1-resistant western corn rootworm, Diabrotica virgifera virgifera (LeConte) does not exhibit cross-resistance to DvSnf7 dsRNA. PLOS ONE 12(1):e0169175

Murdock S, Mullins W W (2006) Roundup ready flex cotton: 2006 launch. In: Proceedings of beltwide cotton conference, San Antonio, TX, 3-6 Jan 2006. National Cotton Council of America, Memphis, TN, pp 2300-2301

National Research Council (2000) Genetically modified pest-protected plants: science and regulation. The National Academies Press, Washington, DC. https://doi.org/10.17226/9795

Niu J, Taning CNT, Christiaens O, Smagghe G, Wang JJ (2018) Rethink RNAi in insect pest control: challenges and perspectives. Adv Insect Physiol 55:1-17

Niu X, Kassa A, Hu X, Robeson J, Mcmahon M, Richtman NM, Steimel JP, Kernodle BM, Crane VC, Sandahl G, Ritland JL, Presnail JK, Lu AL, Wu G (2017) Control of western corn rootworm (Diabrotica virgifera virgifera) reproduction through plant-mediated RNA interference. Sci Rep 7(1):1-13

Oerke EC (2006) Crop losses to pests. J Agric Sci 144(1):31-43

Ohba M, Mizuki E, Uemori A (2009) Parasporin, a new anticancer protein group from Bacillus thuringiensis. Anticancer Res 29(1):427-433

Palma L, Muñoz D, Berry C, Murillo J, Caballero P (2014) Bacillus thuringiensis toxins: an overview of their biocidal activity. Toxins 6(12):3296-3325

Pardo-Lopez L, Soberon M, Bravo A (2013) Bacillus thuringiensis insecticidal three-domain Cry toxins: mode of action, insect resistance and consequences for crop protection. FEMS Microbiol Rev 37(1):3-22

Pline WA, Viator R, Wilcut JW, Edmisten KL, Thomas J, Wells R (2002) Reproductive abnormalities in glyphosate-resistant cotton caused by lower CP4EPSPS levels in the male reproductive tissue. Weed Sci 50(4):438-447

Qaim M (2009) The economics of genetically modified crops. Annu Rev Resour Econ 1(1):665-694

Qin LN, Partridge C (2005) Stimulation of amphiregulin expression in osteoblastic cells by parathyroid hormone requires the protein kinase $\mathrm{A}$ and CAMP response element-binding protein signaling pathway. J Cell Biochem 96(3):632-640

Que Q, Chilton MDM, De Fontes CM, He C, Nuccio M, Zhu T, Wu Y, Chen JS, Shi $L$ (2010) Trait stacking in transgenic crops: challenges and opportunities. GM Crops 1(4):220-229

Raymond B, Johnston PR, Nielsen-Leroux C, Lereclus D, Crickmore N (2010) Bacillus thuringiensis: an impotent pathogen? Trends Microbiol 18(5):189-194
Rembiałkowska E (2007) Quality of plant products from organic agriculture. J Sci Food Agric 87(15):2757-2762

Rosenzweig C, Elliott J, Deryng D, Ruane AC, Müller C, Arneth A, Boote KJ, Folberth C, Glotter M, Khabarov N, Neuman K, Pointek F, Pugh TAM, Schmid E, Stehfest E, Yang H, Jones JW (2014) Assessing agricultural risks of climate change in the 21 st century in a global gridded crop model intercomparison. Proc Natl Acad Sci 111(9):3268-3273

Schnepf HE, Whiteley HR (1985) Delineation of a toxin-encoding segment of a Bacillus thuringiensis crystal protein gene. J Biol Chem 260(10):6273-6280

Sha J, Zhang J, Chi B, Liu R, Li H, Gao J (2018) Sip1Ab gene from a native Bacillus thuringiensis strain QZL38 and its insecticidal activity against Colaphellus bowringi Baly. Biocontrol Sci Technol 28(5):459-467

Shahidi-Noghabi S, Van Damme EJ, Smagghe G (2008) Carbohydrate-binding activity of the type-2 ribosome-inactivating protein SNA-I from elderberry (Sambucus nigra) is a determining factor for its insecticidal activity. Phytochemistry 69(17):2972-2978

Sharma S, Kooner R, Arora R (2017) Insect pests and crop losses. In: Arora R, Sandhu S (eds) Breeding insect resistant crops for sustainable agriculture. Springer, pp 45-66

Shrestha G, Reddy GV, Jaronski ST (2018) Field efficacy of Bacillus thuringiensis galleriae strain SDS-502 for the management of alfalfa weevil and its impact on Bathyplectes spp. parasitization rate. J Invertebr Pathol 153:6-11

Soberón M, López-Díaz JA, Bravo A (2013) Cyt toxins produced by Bacillus thuringiensis: a protein fold conserved in several pathogenic microorganisms. Peptides 41:87-93

Stuitje AR, Verbree EC, Van Der Linden KH, Mietkiewska EM, Nap JP, Kneppers TJ (2003) Seed-expressed fluorescent proteins as versatile tools for easy (co) transformation and high-throughput functional genomics in Arabidopsis. Plant Biotechnol J 1(4):301-309

Swanton CJ, Weise SF (1991) Integrated weed management: the rationale and approach. Weed Technol 5(3):657-663

Torres-Quintero MC, Gómez I, Pacheco S, Sánchez J, Flores H, Osuna J, Mendoza G, Soberón M, Bravo A (2018) Engineering Bacillus thuringiensis Cyt1Aa toxin specificity from dipteran to lepidopteran toxicity. Sci Rep 8(1):1-12

Wang Z, Fang L, Zhou Z, Pacheco S, Gómez I, Song F, Soberón M, Zhang J, Bravo A (2018) Specific binding between Bacillus thuringiensis Cry9Aa and Vip3Aa toxins synergizes their toxicity against Asiatic rice borer (Chilo suppressalis). J Biol Chem 293(29):11447-11458

Wei JZ, Hale K, Carta L, Platzer E, Wong C, Fang SC, Aroian RV (2003) Bacillus thuringiensis crystal proteins that target nematodes. Proc Natl Acad Sci 100(5):2760-2765

Wojtkowski P (2010) Agroecological economics: Sustainability and biodiversity Academic Press

Xu C, Wang BC, Yu Z, Sun M (2014) Structural insights into Bacillus thuringiensis Cry, Cyt and Parasporin Toxins. Toxins 6(9):2732-2770

Yadeta K, Thomma B (2013) The xylem as battleground for plant hosts and vascular wilt pathogens. Front Plant Sci 4(97):1-12

Yamagiwa M, Kamauchi S, Okegawa T, Esaki M, Otake K, Amachi T, Komano T, Sakai H (2001) Binding properties of Bacillus thuringiensis Cry4A toxin to the apical microvilli of larval midgut of Culex pipiens. Biosci Biotechnol Biochem 65(11):2419-2427

Yau YY, Stewart CN (2013) Less is more: strategies to remove marker genes from transgenic plants. BMC Biotechnol 13(1):1-23

Yudina TG, Brioukhanov AL, Zalunin IA, Revina LP, Shestakov AI, Voyushina NE, Chestukhina GG, Netrusov Al (2007) Antimicrobial activity of different proteins and their fragments from Bacillus thuringiensis parasporal crystals against Clostridia and Archaea. Anaerobe 13(1):6-13

Zlobin NE, Lebedeva MV, Taranov VV (2020) CRISPR/Cas9 genome editing through in planta transformation. Crit Rev Biotechnol 40(2):153-168

\section{Publisher's Note}

Springer Nature remains neutral with regard to jurisdictional claims in published maps and institutional affiliations. 